\title{
Nomenclature and taxonomic identities of Prunus zappeyana and P. zappeyana var. subsimplex (Rosaceae)
}

\author{
Bao-Huan Wu', Da-Fang Cui², Ming Kang' \\ I Key Laboratory of Plant Resources Conservation and Sustainable Utilization, South China Botanical Garden, \\ Chinese Academy of Sciences, Guangzhou 510650, China 2 College of Forestry and Landscape Architecture, \\ South China Agricultural University, Guangzhou 510642, China \\ Corresponding author: Bao-Huan Wu (baohuanwu@scbg.ac.cn)
}

Academic editor: A. Sennikov | Received 13 January 2022 | Accepted 8 February 2022 | Published 17 February 2022

Citation: Wu B-H, Cui D-F, Kang M (2022) Nomenclature and taxonomic identities of Prunus zappeyana and P. zappeyana var. subsimplex (Rosaceae). PhytoKeys 190: 47-51. https://doi.org/10.3897/phytokeys. 190.80490

\begin{abstract}
The original specimens of both Prunus zappeyana and P. zappeyana var. subsimplex were found to belong to more than one taxon. In addition, $P$. zappeyana var. subsimplex was found to be invalid because, when the name was published, two separate descriptions were given to two cited collections, but not to the taxon, making the name unaccompanied with a description or diagnosis of this taxon (Art. 38.1 (a)). Therefore, a lectotype of P. zappeyana was designated under Art. 9.11 of ICN, by which P. zappeyana was placed in the synonymy of $P$. veitchii.
\end{abstract}

\section{Keywords}

Cerasus, China, taxonomy, typification

\section{Introduction}

Prunus subg. Cerasus (Mill.) A. Gray is a taxonomically complex group, commonly known as cherries (Liu et al. 2018). There are 39 species or varieties of China recognised in 'Flora of China' (Li and Bartholomew 2003), whose taxonomy remains partly unresolved. A recent study found that original materials containing taxonomically discordant elements may be responsible for some taxonomic confusion in this subgenus (Wu et al. 2019). In our recent work, we found another example of this kind, which we clarify below.

Copyright Wu Bao-Huan et al. This is an open access article distributed under the terms of the Creative Commons Attribution License (CC BY 4.0), which permits unrestricted use, distribution, and reproduction in any medium, provided the original author and source are credited. 
In 1912, Koehne (1912) described P. zappeyana Koehne, based on Wilson 45 and Wilson 70 (part). In the same work, he established a new variety named P. zappeyana var. subsimplex Koehne, based on Wilson $45 a$ and Wilson 3526. After the publication of these two taxa, Schneider (1912) recognised P. zappeyana, but mentioned $P$. zappeyana var. subsimplex as uncertain in his famous dendrological encyclopaedia 'Illustriertes Handbuch der Laubholzkunde'. Thereafter, with no explanation, Silva Tarouca and Schneider (1922) indicated P. zappeyana to be a synonym of P. concinna Koehne (which was treated as a synonym of $P$. veitchii Koehne by Wu et al. (2019)) by placing the former in parentheses following the latter. After that, these two taxa were neglected until $\mathrm{Li}$ and Bartholomew (2003) unexplainably synonymised them with P. trichostoma Koehne, which is totally different from the treatment of Silva Tarouca and Schneider (1922).

To resolve the incongruence between these two taxonomic treatments, in this study, we investigated the nomenclature and the identities of P. zappeyana and P. zappeyana var. subsimplex with the reference to their protologues and original materials.

\section{Results and discussion}

In the protologue of P. zappeyana, Koehne (1912) expressed his concern about the identities of Wilson 45 and Wilson 70, saying that the leaves of the former are larger, while the leaves of the latter are smaller. Similarly, he was somewhat doubtful about the identities of Wilson 45a and Wilson 3526. He did not combine the morphological descriptions of the two collections into a single description as he did when describing other taxa, but gave two descriptions of the two collections separately.

Our examination of the original collections confirmed Koehne's concern on the identities of the original collections, demonstrating that both the original specimens of $P$. zappeyana and P. zappeyana var. subsimplex represent at least two different taxa.

For P. zappeyana, we have successfully sorted out one sheet of Wilson 45 kept at A and two sheets of Wilson 70 kept at $\mathrm{E}$ and US. The specimen of Wilson 45 (A 00032250 , Fig. 1A) consists of a leafy branch with mature fruits and a small leafy branch and obviously belongs to $P$. veitchii Koehne. The leaves on this specimen are obovate-elliptic, $3.5-6.5 \mathrm{~cm}$ long, $1.8-3 \mathrm{~cm}$ broad, with netted veins that are prominent on the leaf back, with leaf margins serrate or biserrate and petioles $0.5-0.8 \mathrm{~cm}$ long. The peduncles are sessile. The fruits are ovoid to nearly globular and black.

In the protologue, Koehne (1912) indicated that Wilson 70 partly belongs to P. zappeyana and partly to P. pilosiuscula var. barbata Koehne. We successfully traced two sheets of Wilson 70 (E 00011305 and US 03718362) kept at E and US, both of which were determined as P. zappeyana by Koehne. However, we have failed to locate any specimen of Wilson 70 that was annotated as P. pilosiuscula var. barbata. The specimen of Wilson 70, housed at E, was determined by T.-T. Yu in July 1948 as $P$. latidentata Koehne (which was reduced as a synonym of $P$. trichostoma in 'Flora Reipublicae Popularis Sinicae' (Yu and Li 1986)) and then was annotated by C.-L. Li in 
1994 as an isotype of P. zappeyana, which was subsequently corrected to a syntype by herbarium curators. It is reasonable to infer that $P$. zappeyana was synonymised by $\mathrm{Li}$ and Bartholomew (2003), based on the specimen of Wilson 70 kept at E. Regarding the identification of these two specimens of Wilson 70, we agree that they can be identified as $P$. trichostoma s.l., but we think they can also be determined as $P$. stipulacea Maxim. which is distinguished from $P$. trichostoma by blossoming slightly before the leaves (or nearly so) and ovate or auriculate stipules on vegetative branches ( $\mathrm{Li}$ and Bartholomew 2003). Both specimens of Wilson 70, kept at E and US, only carry leafy branches with short branchlets and lack the important diagnostic characters.

For P. zappeyana var. subsimplex, we located one sheet each of Wilson $45 a$ (A 00032252, Fig. 1B) and Wilson 3526 (A 00032251) kept at A and E. The specimen of Wilson $45 a$ carries two leafy branches with infructescences and a young leafy branch. This specimen should also be identified as $P$. veitchii. The plants on this specimen show features similar to Wilson 45, such as the obovate-elliptic leaves with serrate or biserrate leaf teeth, sessile peduncles and ovoid to subglobular fruits in black colour. The specimen of Wilson 3526 contains two branches with flower buds that are mostly not open and leaves that are not expanded. This specimen could be identified as P. clarofolia Schneider. The leaves of this specimen are mostly simply serrate and toothed with minute apical glands. The leaf back is pubescent along veins and the petioles are glabrous. The inflorescences are umbellate with 1-2 flowers, with bracts that are toothed with capitate apical glands. The pedicels and hypanthium are glabrous.

According to Art. 9.11 of ICN (Turland et al. 2018), it is necessary to designate the lectotypes of P. zappeyana and P. zappeyana var. subsimplex. However, P. zappeyana var. subsimplex is invalid because, when Koehne (1912) established P. zappeyana var. subsimplex, two descriptions were separately given to the collections, but no combined description under the name directly, making the name unaccompanied by a description of this taxon (Art. 38.1(a)). Therefore, only the lectotypification of P. zappeyana is proposed here.

Either Wilson 45 or Wilson 70 can be chosen as the lectotype of $P$. zappeyana as they both correspond to the original description and match the diagnosis. We prefer to choose Wilson 45 over Wilson 70 as the lectotype of P. zappeyana for two reasons. First, as the identification of Wilson 70 remains taxonomically ambiguous, we prefer to choose Wilson 45 to make the identity of $P$. zappeyana more unambiguous. Second, we think Koehne apparently considered P. zappeyana and P. zappeyana var. subsimplex as belonging to the same species; and Wilson 45 and Wilson $45 a$ are the nomenclatural elements which provide a common taxonomy to link these two names together, though the latter was not validly published.

Therefore, we chose the specimen of Wilson 45 as the lectotype of P. zappeyana and, furthermore, treated $P$. zappeyana as the synonym of $P$. veitchii, based on the lectotype. This decision deviates from the taxonomy of Li and Bartholomew (2003), but agrees with the older interpretation by Silva Tarouca and Schneider (1922). It makes no changes to the currently accepted nomenclature of Chinese cherries, but contributes to its further disambiguation. 

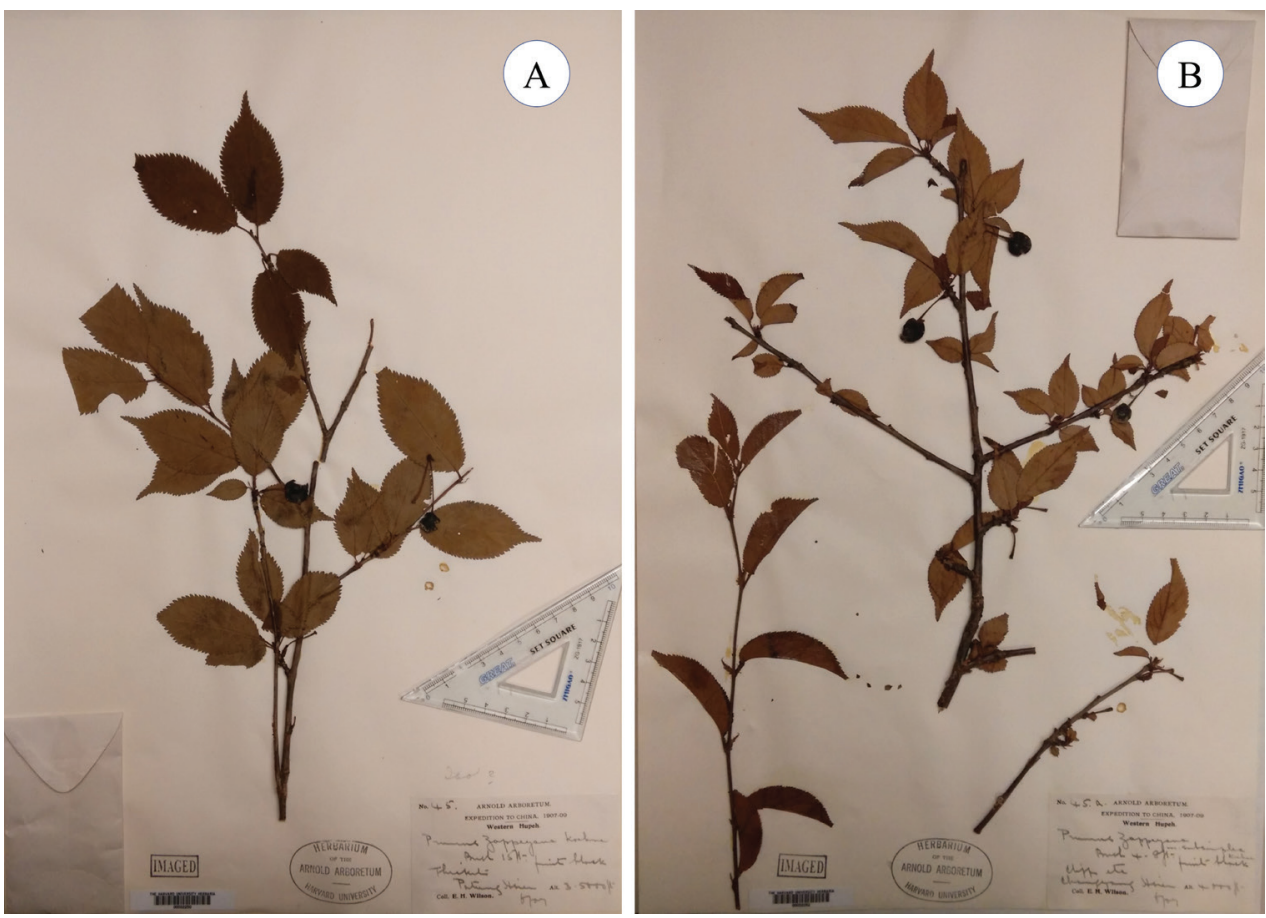

Figure I. Original specimens of Prunus zappeyana and P. zappeyana var. subsimplex A lectotype of P. zappeyana, Wilson 45 (A 00032250) B one of the original specimens of $P$. zappeyana var. subsimplex, Wilson 45a (A 00032252).

\section{Taxonomic treatment}

Prunus veitchii Koehne, Pl. Wilson. (Sargent) 1(2): 257. 1912.

Prunus veitchii Type: China. Western Hubei, April 1900, E.H. Wilson 66 (lectotype designated by Wu et al. (2019: 66), US00130697, image!; isolectotypes E00417568, image!, HBG511147, image! NY00415930, image! A00032230 part, image!)

= Prunus zappeyana Koehne, Pl. Wilson. (Sargent) 1(2): 221. 1912, syn. nov. Type: CHINA. Hubei Province: Badong (Patung) County, alt. 1000-1600 m, June 1907, E.H. Wilson 45 (lectotype designated here: A00032250!) (Fig. 1A). Remaining syntype: China. Hubei, woods, alt. 1300-2000 m, June 1907, E. H. Wilson 70 (E 00011305, image!).

Note. For a full list of synonyms, descriptions and distribution of Prunus veitchii, see

Wu et al. (2019). 


\section{Acknowledgements}

This study was supported by National Natural Science Foundation of China (NSFC31370246) and the Strategic Priority Research Program of Chinese Academy of Sciences (Grant No. XDB31000000). We are grateful to the curators of Herbaria A, E, US and SYS for access to the specimens and the images of specimens. We thank Dr Alexander Sennikov and one anonymous reviewer for their careful reviews.

\section{References}

Koehne BAE (1912) Prunus. In: Sargent CS (Ed.) Plantae Wilsonianae: an enumeration of the woody plants collected in western China for the Arnold arboretum of Harvard University during the years 1907, 1908, and 1910 by E.H. Wilson. Part 2. The University Press, Cambridge, 196-282.

Li C-L, Bartholomew B (2003) Cerasus. In: Wu ZY, Raven PH (Eds) Flora of China, Vol. 9. Science Press \& Missouri Botanical Garden Press, Beijing \& St. Louis, 404-420.

Liu X-H, Sun Z-S, Jiang D-Y, Shi C-G, Li Y-G, Shen X, Yang S-Z (2018) About challenges of flowering cherry industry in China. Zhejiang Linye Keji 38: 77-82.

Schneider CK (1912) Illustriertes Handbuch der Laubholzkunde, Vol. 2. Verlag von Gustav Fischer, Jena, 1250 pp.

Silva Tarouca EE, Schneider CK (1922) Unsere Freiland-Laubgehölze. Hölder-Pichler-Tempsky \& G. Freytag, Wien \& Leipzig, 463 pp.

Turland NJ, Wiersema JH, Barrie FR, Greuter W, Hawksworth DL, Herendeen PS, Knapp S, Kusber WH, Li D-Z, Marhold K, May TW, McNeill J, Monro AM, Prado J, Price MJ, Smith GF [Eds] (2018) International Code of Nomenclature for algae, fungi, and plants (Shenzhen Code) adopted by the Nineteenth International Botanical Congress Shenzhen, China, July 2017. Regnum Vegetabile 159. Koeltz Botanical Books, Glashütten. https://doi.org/10.12705/Code.2018

Wu B-H, Liu C-Y, Potter D, Cui D-F (2019) Taxonomic reconsideration of Prunus veitchii (Rosaceae). PhytoKeys 115: 59-71. https://doi.org/10.3897/phytokeys.115.29219

Yu T-T, Li C-L (1986) Cerasus. In: Yu T-T (Ed.) Flora Reipublicae Popularis Sinicae, Vol. 38. Science Press, Beijing, 41-89. 